\title{
Analisis Pengaruh Capital Adequacy Ratio, Financing To Deposit Ratio, Biaya Operasional Dan Pendapatan Operasional, Dan Non Performing Financing Terhadap Profitabilitas Pada BMT Beringharjo
} (Periode 2009-2014)

\author{
Ainil Fhadilah 1 \\ Institut Agama Islam (IAI) Yasni Bungo \\ E-mail: ainilfhadilah@gmail.com/WA:085285034518
}

Profitability is used to measure the effectiveness of the company in obtaining profits or profits, it is very important to be observed considering that adequate profits are needed to maintain the direction of the source of capital. The fluctuation in the value of Return On Asset (ROA) can be influenced by several other financial ratios such as the Capital Adequacy Ratio (CAR), Financing to Deposit Ratio (FDR), Operating Costs and Operating Income (BOPO), and Non-Performing Financing (NPF) which apply. general in cooperatives and based on financial health assessment guidelines KJKS BMT Law number 35.3 / per / m.kukm / 2007. The research objective was to determine the effect of CAR, FDR, BOPO, and NPF on ROA at BMT Beringharjo Yogyakarta. The data used in this research is the annual financial report data from 2009-2014. This study uses multiple linear regression analysis to examine the effect of CAR, FDR, BOPO, and NPF on ROA at BMT Beringharjo Yogyakarta. The results showed that the independent variables CAR, FDR, BOPO, and NPF simultaneously had a significant effect on the dependent variable ROA. Partially CAR has a positive and significant effect on ROA, FDR has no significant effect on ROA, BOPO has a negative and significant effect on ROA, and NPF has no significant effect on ROA on BMT Beringharjo Yogyakarta. The ability of these four variables to ROA in this study was $99.5 \%$, while the rest was influenced by other factors that were not included in the research model.

Keywords: CAR, FDR, BOPO, NPF, Profitability (ROA), BaitulMaalWatamwil (BMT), Regression.

\begin{abstract}
Abstrak
Profitabilitas digunakan untuk mengukur efektivitas perusahaan dalam memperoleh laba atau keuntungan, sangat penting diamati mengingat keuntungan yang memadai diperlukan untuk mempertahankan arah sumber modal. Naik turun nya nilai Return On Asset (ROA) dapat dipengaruhi oleh beberapa rasio keuangan lainnya seperti Capital Adequacy Ratio (CAR), Financing to Deposit Ratio (FDR), Biaya Operasional dan Pendapatan Operasional (BOPO), dan Non Performing Financing (NPF) yang berlaku umum di koperasi dan berdasarkan pedoman penilaian kesehatan keuangan KJKS BMT Undang-undang nomor 35.3/per/m.kukm/2007. Tujuan penelitian untuk mengetahui pengaruh CAR, FDR, BOPO, dan NPF terhadap ROA pada BMT Beringharjo Yogyakarta. Data yang digunakan dalam penelitian ini adalah data laporan keuangan tahunan dari tahun 2009-2014. Penelitian ini menggunakanan alisis regresi linier berganda untuk menguji pengaruh CAR, FDR, BOPO, dan NPF terhadap ROA pada BMT Beringharjo
\end{abstract}


Yogyakarta. Hasil penelitian menunjukkan bahwa variable independen CAR, FDR, BOPO, dan NPF secara simultan mempunyai pengaruh signifikan terhadap variable dependen ROA. Secara parsial CAR mempunyai pengaruh positif dan signifikan terhadap ROA, FDR tidak berpengaruh signifikan terhadap ROA, BOPO berpengaruh negative dan signifikan terhadap ROA, dan NPF tidak berpengaruh signifikan terhadap ROA pada BMT Beringharjo Yogyakarta. Kemampuan dari keempat variable tersebut terhadap ROA dalam penelitian ini sebesar 99,5\%, sedangkan sisanya dipengaruhi oleh faktor lain yang tidak dimasukkan ke dalam model penelitian.

Kata Kunci: CAR, FDR, BOPO, NPF, Profitabilitas (ROA), BaitulMaal Watamwil (BMT), Regresi.

\section{A. Pendahuluan}

Kebutuhan manusia dari hari ke hari terus bertambah sejalan dengan taraf hidup masing-masing, tetapi di lain pihak kemampuan untuk memenuhi semua kebutuhan tersebut sangat terbatas, sehingga tidak jarang mereka memerlukan bantuan dana pihak ketiga untuk memenuhi kebutuhan perorangan, lembaga keuangan, lembaga perbankan maupun lembaga non perbankan. Salah satu lembaga keuangan syariah yang berkembang pesat adalah lembaga keuangan mikro syariah (BMT). Baitul Maal wat Tamwil (BMT) merupakan organisasi bisnis yang juga berperan sosial, terdiri dari dua istilah, yaitu baitul maal dan baitul tamwil. Baitul maal lebih mengarah pada usahausaha pengumpulan dan penyaluran dana yang non-profit, seperti; zakat, infaq, dan shadaqoh. Sedangkan baitul tamwilsebagai usaha pengumpulan dan penyaluran dana komersial. Usaha-usaha tersebut menjadi bagian yang tidak terpisahkan dari BMT sebagai lembaga pendukung kegiatan ekonomi masyarakat kecil dengan berlandaskan syariah. $^{2}$

Lembaga ini hadir untuk menjembatani kebutuhan masyarakat kecil yangtidak tersentuh oleh lembaga bank. LKM syariah hadir memenuhi jasa keuangan/modal pembiayaan pelaku usaha mikro. ${ }^{3}$ Keberadaan BMT dalam sistem ekonomi sangatlah penting, sehingga BMT harus dikelola dengan baik sebagaimana layaknya sebuah badan usaha. Sedangkanbentuk badan usaha yang paling tepat untuk BMT adalah koperasi. Pengelolaan BMT secara baik akan dapat mengembangkan usahanya sehingga dapat mencapai tujuan BMT itu sendiri, yaitu meningkatkan kualitas usaha ekonomi untuk kesejahteraan anggota pada khususnya dan masyarakat pada umumnya.Analisis keuangan BMT dilakukan dengan menganalisis posisi neraca dan laporan laba rugi. Sampai saat ini analisis rasio keuangan BMT masih menggunakan aturan yang berlaku pada koperasi. Dalam peraturan koperasi, bahwasanya untuk Return On Asset (ROA) minimal 10\% sudah dikatakan sehat. Ketentuan ini berlaku pada setiap koperasi. Selain itu, Menteri Negara Koperasi Usaha Kecil Dan Menengah Republik Indonesia mengeluarkanPeraturan Menteri Nomor: 35.3/Per/M.Kukm/X/2007 tentang Penilaian

\footnotetext{
${ }^{2}$ Sudarsono. 2012. Bank dan Lembaga Keuangan Syariah (Deskripsi dan Ilustrasi), edisi 2, Yogyakarta: Ekonisia Yogyakarta, hal 107

${ }^{3}$ Muhammad. 2009. Lembaga Keuangan Mikro Syariah (pergulatan melawan kemiskinan dan penetrasi ekonomi global), Yoyakarta: Graha ilmu, hal 78
} 
Kesehatan Koperasi dan Jasa Keuangan Syariah dan Unit Jasa Keuangan Syariah Koperasi Indonesia. ${ }^{4}$

Capital Adequacy Ratio (CAR) merupakan indikator yang dijadikan variabel yang mempengaruhi ROA didasarkan hubungannya dengan tingkat risiko kerugian. Semakin tinggi jumlah modal BMT dibandingkan dengan jumlah simpanan sukarela maka tingkat keamanan dana anggota semakin terjamin. Dalam penelitian Bhaskoro (2013) dan Ulya (2015) menunjukkan CAR berpengaruh positif signifikan terhadap ROA. Sedangkan hasil penelitian Wibowo dan Syaichu (2013) dan Pamungkas (2013) menyatakan bahwa CAR tidak berpengaruh terhadap ROA. Financing to Deposit Ratio (FDR) merupakan perbandingan antara pembiayaan yang diberikan oleh bank, dengan dana pihak ketiga yang berhasil dikerahkan oleh bank. ${ }^{5}$ Penelitian yang dilakukan Pamungkas (2013), Ulya (2015), dan Riyadi (2014) menunjukkan bahwa FDR berpengaruh positif signifikan terhadap ROA. Dalam penelitian Bhaskoro (2013) menganalisis bahwa FDR tidak berpengaruh signifikan terhadap ROA.

Rasio Biaya Operasional dan Pendapatan operasional (BOPO) merupakan salah satu rasio yang digunakan untuk mengukur tingkat efisiensi dan kemampuan BMT dalam melakukan kegiatan operasinya. Naik turunnya rasio ini akan mempengaruhi laba yang dihasilkan, karena semakin besar biaya operasional ini maka semakin rendah laba yang diperoleh. dengan tingginya biaya, maka akan menurunkan laba yang dihasilkan BMT, begitu pula sebaliknya. ${ }^{6}$ Dalam penelitian Bhaskoro (2013), Ulya (2015), dan Wibowo dan Syaichu (2013) menyatakan bahwa BOPO berpengaruh signifikan terhadap ROA.

Non Performing Financing (NPF) merupakan rasio keuangan yang berkaitan dengan risiko kredit. Risiko kredit didefinisikan sebagai risiko yang dikaitkan dengan kemungkinan kegagalan nasabah membayar kewajiban, atau risiko dimana debitur tidak dapat melunasi hutangnya. Dari hasil penelitian Pamungkas (2013) menyatakan bahwa NPF berpengaruh negatif signifikan terhadap ROA. Dalam penelitan Wibowo dan Syaichu (2013) dan Riyadi (2014) meyatakan bahwa NPF tidak berpengaruh terhadap ROA.

Tabel 1.1 Kondisi BMT Beringharjo

\begin{tabular}{|c|c|c|c|c|c|}
\hline Tahun & CAR & FDR & BOPO & NPF & ROA \\
\hline 2009 & $4,71 \%$ & $79,83 \%$ & $56,16 \%$ & $7,74 \%$ & $0,61 \%$ \\
\hline 2010 & $8,44 \%$ & $84,21 \%$ & $56,76 \%$ & $8,70 \%$ & $1,08 \%$ \\
\hline 2011 & $6,98 \%$ & $78,49 \%$ & $56,29 \%$ & $9,00 \%$ & $0,76 \%$ \\
\hline 2012 & $7,02 \%$ & $73,38 \%$ & $57,26 \%$ & $8,11 \%$ & $0,89 \%$ \\
\hline 2013 & $5,20 \%$ & $67,00 \%$ & $62,02 \%$ & $7,85 \%$ & $0,37 \%$ \\
\hline 2014 & $6,85 \%$ & $76,33 \%$ & $62,10 \%$ & $7,92 \%$ & $0,68 \%$ \\
\hline
\end{tabular}

Sumber: Data Laporan Keuangan Tahunan BMT Beringharjo (diolah)

\footnotetext{
${ }^{4}$ Peraturan Menteri Negara Koperasi Usaha Kecil Dan Menengah Republik Indonesia Undang-Undang Nomor: 35.3/Per/M.Kukm/X/2007, Jakarta 8 Oktober 2007, hal 1

5 Suwiknyo, Dwi, 2010, Analisis Laporan Keuangan Perbankan Syariah. Yogyakarta: Pustaka Pelajar, hal 148

${ }^{6}$ Sumarsono, Sony. 2003.Manajemen Koperasi Teori Dan Praktik. Yogyakarta: Graha Ilmu, hal 45
} 
Berdasarkan tabel $1.1 \mathrm{di}$ atas bahwasanya data tersebut dapat menggambarkan perkembangan kinerja keuangan di BMT Beringharjo. Terdapat beberapa gap yang tidak sesuai dengan teori yang ada, tingkat kenaikan CAR harusnya berpengaruh positif terhadap ROA. Jika dilihat dari rasio CAR tahun 2009 sebesar 4,71\% dan tahun 2010 sebesar 8,44\% dan penurunan pada tahun 2013 sebesar 5,20\%. Hal ini berdampak negatif pada profitabilitas pada tahun 2013 sebesar 0,37\%. Tingkat kenaikan FDR harusnya berpengaruh positif terhadap ROA. Jika dilihat dari rasio FDR tahun 2012 sebesar 73,38\% dan tahun 2013 sebesar 67,00\%. Hal ini justru berdampak negatif terhadap profitabilitas pada tahun 2012 sebesar $0,89 \%$ mengalami penurunan pada tahun 2013 sebesar 0,37\%.

Tingkat kenaikan BOPO harusnya berpengaruh positif terhadap ROA. Jika dilihat dari rasio BOPO tahun 2012 sebesar 57,26\% dan tahun 2013 sebesar 62,02\%. Hal ini justru berdampak negatif terhadap profitabilitas pada tahun 2012 sebesar 0,89\% dan mengalami penurunan pada tahun 2013 sebesar 0,37\%. Tingkat kenaikan NPF harusnya berpengaruh negatif terhadap ROA. Jika dilihat rasio NPF tahun 2009 sebesar 7,74\% dan tahun 2010 sebesar 8,7\% mengalami kenaikan pada tahun 2011 sebesar 9.0\%. Hal ini justru berdampak positif terhadap profitabilitas sehingga mengalami kenaikan dari 0,61\% ke 1,08\% dan penurunan pada tahun 2011 sebesar 0,76\%. Setiap tahunnya mengalami perubahan secara fluktuatif dengan nilai NPF nya berada pada posisi diatas 5\%.7 Menurut penilaian kesehatan keuangan KJKS BMT Undang-undang nomor 35.3/per/m.kukm/2007 kondisi tersebut termasuk kurang sehat. ${ }^{8}$

Berdasarkan latar belakang diatas yang telah disebutkan dijadikan acuan untuk menentukan indikator yang berpengaruh terhadap profitabilitas pada Lembaga Keuangan Mikro Syariah yang terfokus pada BMT Beringharjo Yogyakarta. Oleh karena itu penulis mengangkat judul skripsi "Analisis Pengaruh Capital Adequacy Ratio (CAR), FinancingTo Deposit Ratio (FDR), Biaya Operasional Dan Pendapatan Operasional (BOPO), dan Non Performing Financing (NPF)Terhadap Profitabilitas Pada BMT Beringharjo Periode 2009-2014".

Penelitian ini merupakan pengembangan penelitian Wibowo dan Syaichu (2013), Riyadi (2014), dan penelitian Ulya (2015). Adapun perbedaan dalam penelitian ini terletak pada penambahan variabel independen yaitu Non Performing Financing (NPF) dan masa pengamatan 6 tahun, dari tahun 2009-2014. Objek penelitian ini adalah di BMT Beringharjo Yogyakarta. Penelitian ini menarik untuk diteliti karena mampu memberikan data terbaru mengenai analisis faktor yang mempengaruhi profitabilitas pada Lembaga Keuangan Mikro Syariah.

\section{B. Landasan Teori}

\section{Lembaga Keuangan}

Menurut undang-undang nomor 10 tahun 1998 tentang pokok-pokok perbankan adalah:

\footnotetext{
7Wawancara bersama bapak Bey Arifin sebagai HRD BMT Beringharjo pada tgl 17 Oktober 2015

${ }^{8}$ Peraturan Menteri Negara Koperasi Usaha Kecil Dan Menengah Republik Indonesia Undang-Undang Nomor: 35.3/Per/M.Kukm/X/2007, Jakarta 8 Oktober 2007, hal 6
} 
"lembaga keuangan adalah semua badan yang melalui kegiatan-kegiatan dibidang keuangan menarik uang dari masyarakat dan menyalurkan uang tersebut kembali ke masyarakat." 9

Dari pengertian diatas, dapat disimpulkan bahwa lembaga keuangan adalah suatu lembaga yang menghimpun dana dari masyarakat dan menyalurkan kembali dana tersebut kepada masyarakat. Lembaga keuangan dikelompokkan menjadi dua, yaitu Lembaga Keuangan Bank (LKB) dan Lembaga Keuangan Bukan Bank (LKBB). Perbedaan diantara keduanya adalah: ${ }^{10}$

1) Kewajiban keuangan LKB dan LKBB, liabilitas LKB berupa uang, sedangkanliabilitas LKBB tidak dapat diklasifikasikan sebagai uang.

2) Kemampuan kedua lembaga keuangan dalam menciptakan kredit dan uang, yaitu LKB mempunyai kemampuan menciptakan kredit, mengedarkan uang, dan menambah jumlah uang yang beredar (JUB) melalui efek pengganda uang.Sedangkan LKBB menyalurkan dana kepada masyarakat terutama melalui penyertaan modal atau membiayai investasi perusahaan.

\section{Pengertian BMT}

BMT adalah singkatan dari Baitul Maal Wat Tamwil, secara etimologi baitul maal berarti rumah dana, sedangkan tamwil berarti usaha (rumah usaha). Menurut sejarahnya BMT mulai digagas pada zaman Rasulullah SAW dan berkembang sampai abad pertengahan. ${ }^{11}$ Dimana fungsi baitul maal sendiri sebagai pengumpulan dana sekaligus mentasyarufkan dana sosial. Dan baitul tamwil sebagai lembaga bisnis. Penjelasan diatas dapat diambil sebuah pengertian bahwa BMT merupakan sebuah lembaga keuangan Islam non bank yang selain menjalankan fungsi bisnis juga berperan sosial dalam sebuah masyarakat.Dengan demikian, keberadaan BMT dapat dipandang memiliki dua fungsi utama, yaitu sebagai media penyalur pendayagunaan harta ibadah seperti zakat, infaq, sedekah, dan wakaf, serta dapat pula berfungsi sebagai institusi yang bergerak dibidang investasi yang bersifat produktif sebagaimana layaknya bank. Pada fungsi kedua ini dapat dipahami bahwa selain berfungsi sebagai lembaga keuangan, BMT juga berfungsi sebagai lembaga ekonomi. Sebagai lembaga keuangan BMT bertugas menghimpun dana dari masyarakat (anggota BMT) yang mempercayakan dananya disimpan di BMT dan menyalurkan dana kepada masyarakat (anggota BMT) yang diberikan pinjaman oleh BMT. Sedangkan sebagai lembaga ekonomi, BMT berhak melakukan kegiatan ekonomi, seperti mengelola kegiatan perdagangan, industri, dan pertanian. ${ }^{12}$

\section{Karakter Profitabilitas}

Tujuan akhir yang ingin dicapai suatu perusahaan yang terpenting adalah memperoleh laba atau keuntungan yang maksimal, memperoleh laba yang maksimal seperti yang ditargetkan, perusahaan dapat berbuat banyak bagi kesejahteraan pemilik, karyawan, serta meningkatkan mutu produk dan melakukan investasi baru. Artinya

\footnotetext{
${ }^{9}$ Ibid. Hal 2

${ }^{10}$ Subagyo dkk. 2002. Bank dan Lembaga Keuangan lainnya, Yogyakarta: STIE YKPN, hal 31.

11Ridwan, Muhammad. 2011. Manajemen Baitul Maal Wat Tamwil. Yogyakarta: UII Press, hal 126

${ }^{12}$ Andri Sumitra. 2009. Bank dan lembaga keuangan syariah. Edisi 1 Cetakan 1. Jakarta: Kencana. hal.
} 448 
besarnya keuntungan haruslah dicapai sesuai dengan yang diharapkan dan bukan asal untung saja, untuk mengukur tingkat keuntungan suatu perusahaan digunakan rasio keuntungan atau rasio profitabilitas yang dikenal juga dengan nama rasio rentabilitas.

\section{Karakter Likuiditas}

Sering sekali terdengar atau bahkan melihat ada perusahaan yang tidak mampu atau tidak sanggup untuk membayar seluruh atau sebagian utang (kewajibannya) yang sudah jatuh tempo pada saat ditagih atau kadang perusahan juga sering tidak memiliki dana untuk membayar kewajibannya tepat waktu. Hal itu terjadi karena perusahaan tidak memiliki dana yang cukup untuk menutupi utang yang jatuh tempo tersebut. Kasus ini akan sangat mengganggu hubungan antara perusahaan dengan para nasabah/kreditor atau juga dengan para destributor sehingga akan menimbulkan krisis kepercayaan dari berbagai pihak, padahal kepercayaan merupakan modal utama perusahaan dalam mencapai target yang ditetapkan. Fred Weston menyebutkan bahwa rasio likuiditas (liquidity ratio) merupakan rasio yang menggambarkan kemampuan perusahaan dalam memenuhi kewajiban (utang) jangka pendek.

Rasio ini juga sering disebut dengan nama rasio modal kerja merupakan rasio yang digunakan untuk mengukur seberapa likuidnya suatu perusahaan. Caranya dengan membandingkan komponen yang ada di neraca (utang jangka pendek). Penilaian dapat dilakukan untuk beberapa periode sehingga terlihat perkembangan likuiditas perusahaan dari waktu ke waktu.Hasil dari penilaian rasio likuiditas yaitu perusahaan mampu memenuhi kewajibannya, dikatakan perusahaan tersebut dalam keadaan likuid. Sebaliknya, apabila perusahaan tidak mampu memenuhi kewajiban tersebut, dikatakan perusahaan dalam keadaan illikuid.

\section{Analisis Laporan Keuangan}

Laporan keuangan merupakan alat yang sangat penting untuk memperoleh informasi sehubungan dengan posisi keuangan perusahaan yang bersangkutan, data keuangan tersebut akan lebih berarti bagi pihak-pihak yang berkepentingan apabila data tersebut diperbandingkan untuk 2 (dua) periode atau lebih, dan di analisis lebih lanjut sehingga dapat diperoleh data yang dapat mendukung keputusan yang diambil. ${ }^{13}$

\section{Kinerja Dalam Perspektif Islam}

Kinerja keuangan berguna untuk menilai kondisi keuangan BMT. Kondisi keuangan BMT dapat dicerminkan dari tingkat likuiditas, struktur permodalan, rentabilitas dan efisiensi BMT yang bersangkutan. Tingkat kesehatan BMT adalah ukuran kinerja dan kualitas BMT. Tingkat kesehatan BMT dapat dilihat dari faktor-faktor penting yang mempengaruhi kelancaran, keberhasilan dan keberlangsungan usaha BMT baik untuk jangka pendek maupun jangka panjang. ${ }^{14}$ Penilaian disini harus bersifat objektif agar dapat diketahui kondisi yang baik dan tepat untuk perusahaan. Al-Quran juga telah memberikan penekanan yang lebih jelas terhadap tenaga kerja manusia, sebagai mana firman Allah SWT:

${ }^{13}$ Suwiknyo. 2010. Analisis laporan keuangan perbankan syariah, Yogyakarta: Pustaka Pelajar, hal 59

${ }^{14}$ Pedoman Kesehatan Ekonomi Syariah (PKES), 2008, hal 23 


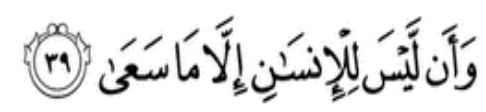

"Dan bahwasanya seorang manusia tiada memperoleh, selain apa yang telah di usahakannya."(QS. An-Najm(53):39)

Ayat diatas menjelaskan bahwa satu-satunya cara untuk mendapatkan sesuatu adalah melalui kerja keras. Semakin bersungguh-sungguh manusia, maka semakin banyak harta yang akan diperolehnya. Ayat diatas juga berkaitan dengan ayat berikut ini QS. Al-Baqarah (2) : 172

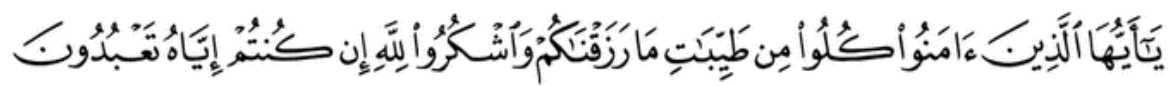

"Hai orang-orang yang beriman, makanlah di antara rezki yang baik-baik yang kami berikan kepadamu dan bersyukurlah kepada Allah, jika benar-benar kepada-Nya kamu menyembah." (QS. Al-Baqarah (2):172)

Dalam memilih seseorang untuk diserahi suatu tugas, Rasulullah SAW melakukannya secara selektif, di antaranya dilihat dari segi keahlian, keutamaan, dan kedalaman ilmunya. Beliau juga selalu mengajak mereka agar tekun dalam menunaikan pekerjaan.

\section{Profitabilitas}

Pada Bank rasio profitabilitas disebut dengan rentabilitas adalah kemampuan suatu perusahaan untuk menghasilkan laba selama periode tertentu. ${ }^{15}$ Profitabilitas perusahaan menunjukkan perbandingan antara laba dengan aktiva atau modal yang menghasilkan laba tersebut. Rasio profitabilitas merupakan rasio kunci yang menunjukkan posisi perusahaan secara keseluruhan.Analisis rasio profitabilitas/rentabilitas adalah alat untuk menganalisis atau mengukur tingkat efisiensi usaha dan profitabilitas yang dicapai oleh suatu bank atau BMT. Rasio-rasio tersebut digunakan untuk mengukur tingkat kesehatan bank dan BMT. ${ }^{16}$ Suatu BMT dapat dimasukkan kedalam klasifikasi sehat apabila tingkat pengembalian atau Return On Asset (ROA) mencapai sekurang-kurangnya 25\%. Makin besar perbandingan laba bersih terhadap jumlah semua modalmenunjukkan keberhasilan perusahaan dalam memperoleh laba. ${ }^{17}$

\section{Profitabilitas dalam Pandangan Islam}

Profitabilitas atau laba dalam bahasa arab mempunyai makna pertumbuhan dalam dagang. Dalam ekonomi Islam, keuntungan diartikan sebagai tambahan dari hasil jual beli atau hasil yang berkaitan dari setiap pekerjaan yang dilakukan. Keuntungan ini adakalanya dinisbahkan kepada pemilik barang atau dinisbahkan kepada barang itu sendiri. Tidak ada batasan tertentu dalam pengambilan keuntungan karena ayat-ayat dan hadits-hadits tentang jual beli tidak menjelaskan tentang batasan tertentu dalam

\footnotetext{
15Ibid, hal 35

16Lukman Dendawijaya. 2000. Manajemen Perbankan. Jakarta: Ghalia Indonesia, hal 120-121

${ }^{17}$ Ibid,hal 157
} 
hal tersebut. akan tetapi, bahwa dalam pengambilan keuntungan tidak dibolehkan melebihkan keuntungan yang bisa membahayakan orang lain. Al-Qur'an telah menerangkan mengenai istilah ini melalui firmannya, Allah SWT berfirman dalam QS.AlBaqarah ayat 16 :

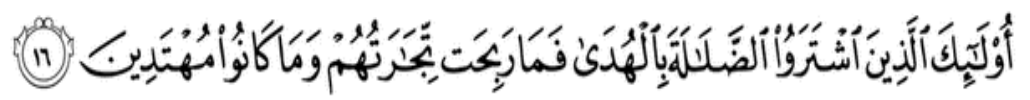

"Mereka itulah orang yang membeli kesesatan dengan petunjuk maka tidaklah beruntung perniagaan mereka dan tidaklah mereka mendapat petunjuk". (QS.Al-Baqarah(2):16)

At-Tabari mengulas ayat tersebut dengan menyatakan bahwa seseorang yang melakukan perniagaan akan memperoleh keuntungan apabila ia melakukan aktivitas pertukaran komoditas yang dimilikinya dengan komoditas lainnya yang berharga. Sebaliknya jika ia menukarkan komoditas yang dimilikinya dengan komoditas yang lebih murah maka perniagaan tersebut akan mengalami kerugian. Berdasarkan ta'rifini, dapat disimpulkan bahwa keuntungan akan diperoleh apabila suatu barang itu dijual dengan harga lebih tinggi dariapada pengeluarannya.

\section{Return On Asset (ROA)}

ROA merupakan indikator kemampuan perbankan untuk memperoleh laba atas sejumlah aset yang dimiliki oleh bank. ROA dapat diperoleh dengan cara menghitung rasio antara laba setelah pajak dengan total aktiva (Net Income dibagi Total Asset). ${ }^{18}$ Berdasarkan Peraturan Menteri Nomor: 35.3/Per/M.Kukm/X/2007 tentang Penilaian Kesehatan Koperasi dan Jasa Keuangan Syariah dan Unit Jasa Keuangan Syariah Koperasi Indonesia bahwa Rentabilitas Asset (ROA) adalah kemampuan aktiva yang digunakan dalam menghasilkan Sisa Hasil Usaha.

$$
\mathrm{ROA}=\frac{\text { SHUsebelumnisbah,zakatdanpajak }}{\text { Totalaset }} \times 100 \%
$$

Tabel 2.2 Kriteria Penilaian ROA

\begin{tabular}{|c|c|c|}
\hline $\begin{array}{c}\text { Rasio Rentabilitas } \\
\text { Aset (\%) }\end{array}$ & Kriteria & Peringkat \\
\hline$<5$ & Rendah & 4 \\
\hline $5-7,4$ & Kurang & 3 \\
\hline $7,5-10$ & Cukup & 2 \\
\hline$>10$ & Tinggi & 1 \\
\hline
\end{tabular}

Sumber: Peraturan Menteri Negara UMKM Indonesia Tahun 2007

\section{Capital Adequacy Ratio (CAR)}

Capital Adequacy Ratio (CAR) atau sering disebut rasio permodalan merupakan rasio yang menunjukkan tingkat kecukupan modal BMT dibandingkan dengan jumlah simpanan sukarela. BMT yang mempunyai tingkat kecukupan modal yang baik menunjukkan indikator bahwa BMT tersebut sehat. Modal ini digunakan untuk menjaga

18Pandia, Frianto. 2012. Manajemen Dana dan Kesehatan Bank. Jakarta: Rineka Cipta, hal 71 
kepercayaan masyarakat terhadap kinerja BMT. Capital Adequacy Ratio (CAR) adalah perbandingan antara modal sendiri dengan kebutuhan modal yang tersedia setelah dihitung pertumbuhan risiko (margin risk) dari akibat yang berisiko. ${ }^{19}$

Tabel 2.3 Kriteria Penilaian Rasio CAR

\begin{tabular}{|c|c|}
\hline Rasio CAR (\%) & Kriteria \\
\hline$<6$ & Tidak Sehat \\
\hline $6-<7$ & Kurang Sehat \\
\hline $7-<8$ & Cukup Sehat \\
\hline$\geq 8$ & Sehat \\
\hline
\end{tabular}

Sumber: Peraturan Menteri Negara UMKM Indonesia Tahun 2007

\section{Financing to Deposit Ratio (FDR)}

Financing to Deposit Ratio (FDR) merupakan rasio yang menggambarkan tingkat efisiensi pelaksanaan fungsi bank sebagai intermediasi dalam menghimpun dana dan pengalokasian. FDR ditentukan oleh perbandingan antara jumlah pinjaman yang diberikan dengan dana masyarakat yang dihimpun yaitu mencakup giro, simpanan berjangka (deposito), dan tabungan. FDR menyatakan seberapa jauh kemampuan bank dalam membayar kembali penarikan dana yang akan dilakukan deposan dengan mengandalkan pembiayaan yang diberikan sebagai sumber likuiditasnya. Semakin tinggi rasio FDR maka bank tersebut semakin baik dalam menjalankan fungsi intermediasinya. Namun dalam menjalankan fungsi intermediasinya, bank juga perlu untuk tetap memperhatikan ketersediaan dana untuk memenuhi kebutuhan para deposannya saat mengambil dana. ${ }^{20}$

Tabel 2.4 Kriteria Penilaian Pembiayaan (FDR)

\begin{tabular}{|c|c|}
\hline Rasio Pembiayaan (\%) & Kriteria \\
\hline$<50$ & Tidak Likuid \\
\hline $51-75$ & Kurang Likuid \\
\hline $76-100$ & Cukup Likuid \\
\hline$>100$ & Likuid \\
\hline
\end{tabular}

Sumber:Peraturan Menteri Negara UMKM Indonesia Tahun 2007

\section{Biaya Operasional dan Pendapatan Operasional (BOPO)}

Rasio biaya adalah rasio yang menunjukkan tingkat efisiensi kinerja operasional BMT. Efisiensi yang diproksikan menggunakan BOPO dapat diartikan sebagai kemampuan BMT mengendalikan biaya operasional untuk menghasilkan pendapatan operasional tertentu. Biaya operasional meliputi biaya bagi hasil simpanan, overhead cost seperti listrik, karyawan, telepon, biaya penagihan dan lain-lain. Pendapatan operasional terdiri dari pendapatan bagi hasil, mark up, dan hasil kegiatan pendanaan suatu usaha nasabah. Efisiensi usaha BMT dapat diukur dengan menghitung rasio

${ }^{19}$ Muchdarsyah, Sinangun. 1999. Manajemen Dana Bank. Jakarta: PT. Bumi Aksara, hal 157

${ }^{20}$ Muhammad, Ghofur W. 2007. Potret Perbankan Syariah Indonesia Terkini (kajian kritis perkembangan perkembangan. Yogyakarta: Biruni Press, hal 38 
antara biaya operasional dengan pendapatan operasional. Jika rasionya $>1$ berarti BMT mengalami kerugian dan bila $<1$ berarti BMT mendapat keuntungan. ${ }^{21}$

Tabel 2.5 Kriteria Penilaian BOPO

\begin{tabular}{|c|c|}
\hline $\begin{array}{c}\text { Rasio Biaya Operasional } \\
\text { terhadap Pelayanan (\%) }\end{array}$ & Kriteria \\
\hline$>100$ & Tidak Efisien \\
\hline $85-100$ & Kurang Efisien \\
\hline $69-84$ & Cukup Efisien \\
\hline $0-68$ & Efisien \\
\hline \multicolumn{2}{|c|}{ Sumber:Peraturan Menteri Negara UMKM Indonesia Tahun 2007 }
\end{tabular}

\section{Non Performing Financing (NPF)}

Non Performing Financing (NPF) merupakan pembiayaan macet, ini sangat berpengaruh terhadap keuntungan Bank Syariah atau BMT. NPF erat kaitannya dengan pembiayaan yang disalurkan oleh bank syariah kepada nasabahnya. Apabila NPF menunjukkan nilai yang rendah diharapkan pendapatan akan meningkat sehingga laba yang dihasilkan akan meningkat, namun sebaliknya apabila nilai NPF tinggi maka pendapatan akan menurun sehingga laba yang didapat akan turun. ${ }^{22}$

Tabel 2.6 Kriteria Penilaian NPF

\begin{tabular}{|c|c|}
\hline $\begin{array}{c}\text { Rasio piutang bermasalah dan pembiayaan } \\
\text { bermasalah terhadap piutang dan } \\
\text { pembiayaan yang disalurkan (\%) }\end{array}$ & Kriteria \\
\hline$>12$ & Tidak Lancar \\
\hline $9-11$ & Kurang Lancar \\
\hline $5-8$ & Cukup Lancar \\
\hline$<5$ & Lancar \\
\hline
\end{tabular}

Sumber: Peraturan Menteri Negara UMKM Indonesia Tahun 2007

\section{Metode Penelitian}

Penelitian ini dilakukan di KJKS BMT Beringharjo Jl. Ringroad Barat Gamping Sleman Yogyakarta Telp. (0274) 549152/549157.Penelitian ini menggunakan jenis penelitian kuantitatif.Sumber data yang diambil dari semua elemen yang ada dalam wilayah penelitian, yaitu data laporan keuangan tahunan periode 2009-2014. Jenis data yang digunakan dalam penelitian ini adalah data sekunder. Objek penelitian ini terdiri dari dua variabel, yaitu variabel independen/bebas dan variabel dependen/terikat. Variabel independen dan dependen yang dipakai dalam penelitian ini adalah sebagai berikut:1). Variabel dependen/terikat, yaitu:(Y)= Return On Asset (ROA), 2). Variabel

21PINBUK. Pedoman Penilaian Kesehatan Baitul Maal Wat Tamwil (BMT). Jakarta: PINBUK, hal 15

${ }^{22}$ Slamet Riyadi dan Agung Yulianto. 2014. "Pengaruh Pembiayaan Bagi Hasil, Pembiayaan Jual Beli, Fiancing To Deposit Ratio (FDR), dan Non Performing Financing (NPF) terhadap Profitabilitas Bank Umum Syariah Devisa Di Indonesia". Accounting Analysis Journal, Unnes Semarang, hal 56 
independen/bebas, yaitu:(X1) = Capital Adequacy Ratio (CAR), (X2)= Financing To Deposit Ratio(FDR), (X3) = Biaya Operasional dan Pendapatan Operasional (BOPO), (X4= Non Performing Financing (NPF). Populasi yang digunakan dalam penelitian adalah keseluruhan informasi keuangan yang terdapat di BMT Beringharjo dari tahun 20092014.Pengambilan sampel dalam penelitian ini dilakukan dengan teknik Purposive Sampling yaitu teknik sampling yang digunakan peneliti jika peneliti mempunyai pertimbangan-pertimbangan tertentu didalam pengambilan sampelnya atau penentuan sampel untuk tujuan tertentu. ${ }^{23}$

\section{Hasil Analisis dan Pembahasan}

\section{Analisis Data}

Tabel 4.8 Nilai Koefisien Regresi Berganda

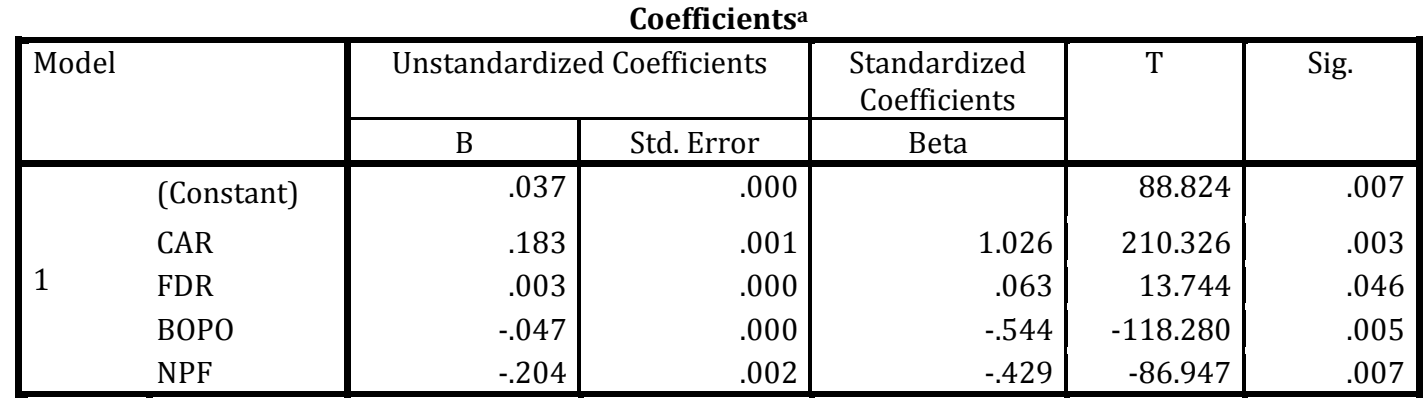

a. Dependent Variable: ROA

Sumber: Data Output SPSS V. 21 (diolah)

Berdasarkan hasil ouput pada tabel 4.8 diatas, diperoleh nilai $\alpha$ sebesar 0.037 , nilai $\beta$ sebesar 0,183 , nilai $\beta_{2}$ sebesar 0,003 , nilai $\beta_{3}$ sebesar $-0,047$, dan nilai $\beta_{4}$ sebesar $-0,204$, dengan demikian dapat dibentuk persamaan regresi linear berganda sebagai berikut:

$$
\text { ROA = 0,037 + 0,183 CAR + 0,003 FDR - 0,047 BOPO - 0,204 NPF }
$$

Tabel 4.9 Uji Koefisien Determinasi Model Summary

\begin{tabular}{|l|r|r|r|r|}
\hline Model & R & R Square & Adjusted R Square & \multicolumn{1}{c|}{$\begin{array}{c}\text { Std. Error of the } \\
\text { Estimate }\end{array}$} \\
\hline 1 & $1.000^{\mathrm{a}}$ & 1.000 & 1.000 & .0000158 \\
\hline
\end{tabular}

a. Predictors: (Constant), NPF, FDR, BOPO, CAR

Sumber: Data Output SPSS V. 21 (diolah)

Berdasarkan hasil uji determinasi yang tampak pada tabel 4.9 diatas, besarnya nilai koefisien determinan atau adjusted $\mathrm{R}^{2}$ adalah 1,000 hal ini berarti $100 \%$ varian ROA dapat dijelaskan oleh variasi dari empat variabel yang berpengaruh terhadap ROA.

Tabel 4.10Uji Signifikansi Simultan (Uji Statistik F)

\footnotetext{
${ }^{23}$ Ibid, hal 10 dan 20
} 
Ainil Fhadilah : Analisis Pengaruh Capital ....

ANOVA $^{\mathrm{a}}$

\begin{tabular}{|l|r|r|r|r|r|}
\hline Model & Sum of Squares & df & Mean Square & F & Sig. \\
\hline Regression & .000 & 4 & .000 & 29433.242 & $.004 \mathrm{~b}$ \\
Residual & .000 & 1 & .000 & & \\
Total & .000 & 5 & & & \\
\hline
\end{tabular}

a. Dependent Variable: ROA

b. Predictors: (Constant), NPF, FDR, BOPO, CAR

Sumber: Data Output SPSS V. 21 (diolah)

Hasil uji F pada tabel 4.10 diperoleh $\mathrm{F}$ hitung $=236.651$ dengan nilai sig. $=0.004$ $<0.05$, yang artinya nilai signifikansi lebih kecil daripada alpha (0.05) sehingga dapat disimpulkan bahwa Ho ditolak, yang berarti terdapat pengaruh secara simultan Capital Adequacy Ratio (CAR), Financing to Deposit Ratio (FDR), Biaya Operasional dan Pendapatan Operasional (BOPO), dan Non performing Financing (NPF), terhadap Return On Asset (ROA).

Tabel 4.11Uji Signifikansi Parameter Individual (Uji statistik t) Coefficients $^{\mathrm{a}}$

\begin{tabular}{|c|c|c|c|c|c|c|}
\hline \multirow[t]{2}{*}{ Mod } & & \multicolumn{2}{|c|}{ Unstandardized Coefficients } & \multirow{2}{*}{$\begin{array}{c}\begin{array}{c}\text { Standardized } \\
\text { Coefficients }\end{array} \\
\text { Beta }\end{array}$} & \multirow[t]{2}{*}{$\mathrm{T}$} & \multirow[t]{2}{*}{ Sig. } \\
\hline & & $\mathrm{B}$ & Std. Error & & & \\
\hline \multirow{5}{*}{1} & (Constant) & .037 & .000 & & 88.824 & .007 \\
\hline & CAR & .183 & .001 & 1.026 & 210.326 & .003 \\
\hline & FDR & .003 & .000 & .063 & 13.744 & .046 \\
\hline & BOPO & -.047 & .000 & -.544 & -118.280 & .005 \\
\hline & NPF & -.204 & .002 & -.429 & -86.947 & .007 \\
\hline
\end{tabular}

a. Dependent Variable: ROA

Sumber: Data Output SPSS V. 21 (diolah)

Berdasarkan tabel 4.11 diatas, secara parsial variabel Capital Adequacy Ratio (CAR) berpengaruh signifikan terhadap Return On Asset (ROA). Hal ini dapat terlihat dari t-hitung $=210.326$ dengan signifikansi $0.003<0.05$, variabel Capital Adequacy Ratio (CAR) memiliki koefisien sebesar 0.183 , hasil uji t ini menunjukkan bahwa $\mathrm{H}_{1}$ yang menyatakan bahwa Capital Adequacy Ratio (CAR) berpengaruh positif dan signifikan terhadap Return On Asset (ROA) diterima.Berdasarkan tabel 4.11 diatas, secara parsial variabel Financing to Deposit Ratio (FDR) berpengaruh signifikan terhadap Return On Asset (ROA). Hal ini dapat dilihat dari t-hitung = 13.744 dengan signifikansi $0.046<0.05$, variabel FDR memiliki koefisien regresi sebesar 0,003 hasil uji ini menunjukkan bahwa $\mathrm{H}_{2}$ yang menyatakan bahwa berpengaruh positif dan signifikan terhadap Return On Asset (ROA) diterima.

Berdasarkan tabel 4.11, secara parsial variabel Biaya Operasional dan Pendapatan Operasional (BOPO) berpengaruh negatif dan signifikan terhadap Return On Asset (ROA). Hal ini dapat terlihat dari t-hitung $=-118.280$ dengan signifikansi $0.005<$ 0.05, variabel Biaya Operasional dan Pendapatan Operasional (BOPO) memiliki koefisien sebesar -0,047, hasil uji t menunjukkan bahwa $\mathrm{H}_{3}$ yang menyatakan Biaya Operasional 
dan Pendapatan Operasional (BOPO) berpengaruh negatif dan signifikan terhadap Return On Asset (ROA) di terima. Berdasarkan tabel 4.11, secara parsial variabel Non Performing Financing (NPF) berpengaruh negatif signifikan terhadap Return On Asset (ROA). Hal ini dapat dilihat dari t-hitung = -86.947 dengan signifikansi $0.007<0.05$, variabel Non Performing Financing (NPF) memiliki koefisien sebesar -0,204, hasil uji t menunjukkan bahwa $\mathrm{H}_{4}$ yang menyatakan Non Performing Financing (NPF) berpengaruh negatif signifikan terhadap Return On Asset (ROA) di terima.

\section{Pembahasan}

\section{a. Analisis Pengaruh Capital Adequacy Ratio (CAR) terhadap Return On Asset} (ROA)

Hasil persamaan regresi diperoleh besarnya koefisien Capital Adequacy Ratio (CAR) sebesar 0,183 dengan tingkat signifikansi sebesar 0,003, sehingga sig. < 0,05. Karena nilai signifikansi lebih kecil maka hipotesis diterima, artinya variabel Capital Adequacy Ratio (CAR) secara parsial mempunyai pengaruh positif dan signifikan terhadap ROA. Semakin tinggi rasio CAR maka semakin baik kondisi suatu bank dan jika nilai CAR tinggi berarti bank mampu membiayai kegiatan operasinya. ${ }^{24} \mathrm{Hal}$ ini sesuai dengan hipotesis yang mengatakan bahwa CAR berpengaruh positif dan signifikan terhadap ROA.

\section{b. Analisis Pengaruh Financing to Deposit Ratio (FDR) terhadap Return On Asset (ROA)}

Hasil penelitian ini menunjukkan bahwa nilai koefisien regresi Financing to Deposit Ratio (FDR) sebesar 0,003 dengan tingkat signifikan 0,046 yang lebih besar dari alpha 0,05. Hal ini menunjukkan Financing to Deposit Ratio (FDR) memiliki arah positif signifikan terhadap profitabilitas (ROA). Sehingga Financing to Deposit Ratio (FDR) berpengaruh positif dan signifikan terhadap Return On Asset (ROA).

c. Analisis Pengaruh Biaya Operasional dan Pendapatan Operasional (BOPO) terhadap Return On Asset (ROA)

Hasil persamaan regresi diperoleh besarnya koefisien Biaya Operasional dan Pendapatan Operasional (BOPO) sebesar -0,047 dengan tingkat signifikansi sebesar 0,005, sehingga sig. $<0,05$. Karena nilai signifikansi lebih kecil maka hipotesis diterima, artinya variabel Biaya Operasional dan Pendapatan Operasional (BOPO) secara parsial mempunyai pengaruh negatif dan signifikan terhadap ROA.

\section{d. Analisis Pengaruh Non Performing Financing (NPF) terhadap Return On Asset (ROA)}

Hasil persamaan regresi diperoleh hasil dari t-hitung $=-86.947$ dengan signifikansi 0.007 lebih besar dari tingkat signifikansi yang digunakan yaitu 0.05 , variabel Non Performing Financing (NPF) memiliki koefisien sebesar -0.204, hasil uji t menunjukkan bahwa H4 yang menyatakan Non Performing Financing (NPF) berpengaruh negatif signifikan terhadap Return On Asset (ROA) di terima.

\footnotetext{
${ }^{24}$ Dendawijaya, Lukman. Manajemen Perbankan, Jakarta: Ghalia Indonesia, 2005, hal 121
} 


\section{E. Kesimpulan}

1. Hasil analisis regresi menunjukkan bahwa secara parsial variabel Capital Adequacy Ratio (CAR) berpengaruh positif dan signifikan terhadap Return On Asset (ROA). Hal ini dapat terlihat dari t-hitung $=0.789$ dengan signifikansi 0.003 lebih kecil dari tingkat signifikansi yang digunakan yaitu 0.05, variabel Capital Adequacy Ratio (CAR) memiliki koefisien sebesar 0.183 , hasil uji t ini menunjukkan bahwa $\mathrm{H}_{1}$ yang menyatakan bahwa Capital Adequacy Ratio(CAR) berpengaruh positif dan signifikan terhadap Return On Asset (ROA) diterima.

2. Hasil analisis regresi menunjukkan bahwa secara parsial variabel Financing to Deposit Ratio (FDR), berpengaruh positif signifikan terhadap Return On Asset (ROA). Hal ini dapat dilihat dari t-hitung $=0.130$ dengan signifikansi 0.046 lebih kecil dari tingkat signifikan yaitu 0.05, variabel FDR memiliki koefisien regresi sebesar 0.003, hasil uji ini menunjukkan bahwa $\mathrm{H}_{2}$ yang menyatakan bahwa berpengaruh positif dan signifikan terhadap Return On Asset (ROA) di terima.

3. Berdasarkan hasil analisis regresi menunjukkan bahwa secara parsial variabel Biaya Operasional dan Pendapatan Operasional (BOPO) berpengaruh negatif dan signifikan terhadap Return On Asset (ROA). Hal ini dapat terlihat dari t-hitung = -118.280 dengan signifikansi 0.005 lebih kecil dari tingkat signifikansi yang digunakan yaitu 0.05, variabel Biaya Operasional dan Pendapatan Operasional (BOPO) memiliki koefisien sebesar -0.047 , hasil uji t menunjukkan bahwa $\mathrm{H}_{3}$ yang menyatakan Biaya Operasional dan Pendapatan Operasional (BOPO) berpengaruh negatif dan signifikan terhadap Return On Asset (ROA) di terima.

4. Berdasarkan hasil analisis regresi menunjukkan bahwa secara parsial Non Performing Financing (NPF) berpengaruh signifikan terhadap Return On Asset (ROA). Hal ini dapat dilihat dari t-hitung = -86.947 dengan signifikansi 0.007 lebih kecil dari tingkat signifikansi yang digunakan yaitu 0.05, variabel Non Performing Financing (NPF) memiliki koefisien sebesar -0.204, hasil uji t menunjukkan bahwa $\mathrm{H}_{4}$ yang menyatakan Non Performing Financing (NPF) berpengaruh negatif signifikan terhadap Return On Asset (ROA) di terima.

5. Secara simultan variabel Capital Adequacy Ratio (CAR), Financing to Deposit Ratio (FDR), Biaya Operasional dan Pendapatan Operasional (BOPO), dan Non Performing Financing (NPF) mempengaruhi tingkat profitabilitas (ROA) dengan nilai signifikansinya sebesar 0,004<0,05 dan nilai F hitungnya sebesar 29433.242.

\section{DAFTAR PUSTAKA}

\section{Al-Qur'an}

Al-Qur'an Al-Karim. 2002. dan Terjemahannya Departemen Agama RI, Semarang: PT. Karya Toha Putra.

\section{Buku-buku}

Arifin, Zainun. 2002. Dasar-dasar Manajemen Bank Syariah. Jakarta: Alfabet: UPP YKPN. Dendawijaya, Lukman. 2005. Manajemen Perbankan, Jakarta:Ghalia Indonesia. 
Ghazali, Imam. 2013. Aplikasi Analisis Multivariate Dengan Program IBM SPSS 21. Semarang: Badan Penerbit Universitas Diponegoro.

Hadits Shahih Syaikh Al-Albany dalam Irwa'ul Ghalih no. 896 diringkas dari Jâmi'ul 'Ulûm wal Hikam (II/212).

Hanafi, Mamduh M., 2005, Analisis Laporan Keuangan, edisi ke-2, Yogyakarta: UPP AMP YKPN.

Imam, Rusyamsi. 2010. Aset Liability Management: Strategi Pengelolaan Aktiva Pasiva Bank. Yogyakarta.

Kasmir. 2010. Analisis Laporan Keuangan. Jakarta: Raja Grafindo Persada.

Ketut, Rindjin. 2000. Pengantar Perbankan dan Lembaga Keuangan Bukan Bank. Jakarta: Gramedia Pustaka Utama.

Kuncoro. 2009. Metode Riset Untuk Bisnis dan Ekonomi (Bagaimana meneliti dan menulis tesis), edisi 3, Jakarta: Erlangga.

Lulail Yunus, Jamal. 2009. Manajemen Bank Syariah Mikro. UIN Malang Press.

Mudrajat Kuncoro dan Suharjhono. 2009. Manajemen Perbankan. Jakarta: Erlangga.

Martono. 2002. Bank dan Lembaga Keuangan Lain. Yogyakarta: Ekonisia.

Muhammad. 1998. Manajemen Baitul Maal Wa Tamwil (BMT). Yogyakarta: STIS

Muhammad. 2005. Manajemen Dana Bank Syariah. Yogyakarta: Ekonomi FE UII.

Muhammad. 2009. Lembaga Keuangan Mikro Syariah (pergulatan melawan kemiskinan dan penetrasi ekonomi global). Yoyakarta: Graha ilmu.

Muhammad, Ghofur W. 2007. Potret Perbankan Syariah Indonesia Terkini (kajian kritis perkembangan perkembangan. Yogyakarta: Biruni Press.

Munawir. 2001.Analisis Laporan Keuangan, Yogyakarta:BPFE.

Muchdarsyah, Sinangun. 1999. Manajemen Dana Bank. Jakarta: PT. Bumi Aksara.

Pandia, Frianto. 2012. Manajemen Dana dan Kesehatan Bank. Jakarta: Rineka Cipta.

Peraturan Menteri Negara Koperasi Usaha Kecil Dan Menengah Republik Indonesia Undang-Undang Nomor: 35.3/Per/M.Kukm/X/2007, Jakarta 8 Oktober 2007

Pedoman Kesehatan Ekonomi Syariah (PKES), 2008.

PINBUK. Pedoman Penilaian Kesehatan Baitul Maal Wat Tamwil (BMT). Jakarta: PINBUK.

Ridwan, Hasan. 2013. Manajemen Baitul Maal Wat Tamwil. Bandung: Pustaka Setia.

Ridwan, Muhammad. 2011. Manajemen Baitul Maal Wat Tamwil. Yogyakarta: UII Press.

Riduwan. 2003. Dasar-Dasar Statistika. Bandung: Alfabeta.

Riyanto, Bambang. 2001. Dasar-dasar Pembelanjaan Perusahaan. Edisi 4. Yogyakarta: BPFE.

Slamet Riyadi. 2006. Banking Aset and Liability Management. Jakarta: Lembaga Penerbit FE UI.

Subagyo dkk. 2002 Bank dan Lembaga Keuangan lainnya. Yogyakarta: STIE YKPN.

Sudarsono. 2012. Bank dan Lembaga Keuangan Syariah (Deskripsi dan Ilustrasi), edisi 2. Yogyakarta: Ekonisia Yogyakarta.

Suwiknyo, Dwi. 2010. Analisis laporan keuangan perbankan syariah. Yogyakarta: Pustaka Pelajar.

Sumarsono, Sony. 2003. Manajemen Koperasi Teori Dan Praktik. Yogyakarta: Graha Ilmu. Sartono, R. Agus. 2001. Manajemen Keuangan Teori dan Aplikasi. Yogyakarta: BPFE.

Sugiono. 2010. Metode Penelitian Kuantitatif, Kualitatif Dan R \& D. Bandung: Alfabeta.

Supardie, Didik Ahmad. 2003. Sistem Lembaga Keuangan Ekonomi Syariah dalam Pemberdayaan Ekonomi Rakyat. Semarang: PT. Pustaka Rizki. Cetakan 1.

Sumitra, Andri. 2009. Bank dan lembaga keuangan syariah. Edisi 1 Cetakan 1. Jakarta: Kencana. 
Taswan. 2010. Manajemen Perbankan (Konsep, Teori dan Aplikasi). Yogyakarta: UPP STIM YKPN Yogyakarta.

Wawancara bersama bapak Bey Arifin sebagai HRD BMT Beringharjo pada tgl 17 Oktober 2015

\section{Jurnal/Skripsi}

Aditia Yusuf Bayu Fadila, 2015, "Analisis Pengaruh Faktor Internal dan Eksternal Bank terhadap Profitabilitas Bank Umum Syariah periode 2010-2014", Skripsi Universitas Muhammadiyah Yogyakarta.

Almuntahanatul Ulya. 2015,"Pengaruh CAR, FDR, BOPO, dan DPK terhadap tingkat profitabilitas pada KSU syariah BMT Kompak", Skripsi UIN Sunan Kalijaga.

Bhaskoro Try Pamungkas. 2013 "Pengaruh CAR, FDR, NPF dan BOPO terhadap ROA pada Bank Umum Syariah (Studi kasus pada Bank Umum Syariah di Indonesia tahun 2009-2012)", Skripsi Mercu Buana.

Riyadi Budi Susanto. 2013, "Pengaruh Capital Adequacy Ratio (CAR), Loan To Deposit Ratio (LDR), Biaya Operasional Dan Pendapatan Operasional (BOPO), Dana Pihak Ketiga (DPK), dan Kualitas Aktiva Produktif(KAP) terhadap tingkat profitabilitas pada Bank Muamalat", Skripsi UIN Sunan Kalijaga Yogyakarta.

Riyadi, Slamet dan Agung Yulianto. 2014."Pengaruh Pembiayaan Bagi Hasil, Pembiayaan Jual Beli, Fiancing To Deposit Ratio (FDR), dan Non Performing Financing (NPF) terhadap Profitabilitas Bank Umum Syariah Devisa Di Indonesia". Accounting Analysis Journal, Unnes Semarang.

Wibowo, Edhi Satrio dan Muhammad Syaichu.2013, "Analisis Pengaruh Suku Bunga, Inflasi, CAR, BOPO, NPF Terhadap Profitabilitas Bank Syariah".Jurnal Program

\section{Website} Studi Manajemen Fakultas Ekonomika dan Bisnis UNDIP.

http://munas3pbmtindonesia.com/ diakses pada tanggal 6-8 oktober 2015.

www.BMTBeringharjo.com diakses tanggal 29 Januari 2016. 